\title{
Edukacja globalna dzieci w zakresie kształtowania krajobrazu - Global Garden Project Praia (Republika Zielonego Przylądka)
}

Streszczenie: Globalna edukacja szczególny nacisk kładzie na ukazywanie relacji między jednostką i procesami globalnymi (Lipska-Badoti i in., 2011), do których zaliczają się zmiany w krajobrazie. Sprzyja ona kształtowaniu postaw odpowiedzialnych już od najmłodszych lat, niezależnie od miejsca zamieszkania. Praca prezentuje wyniki badań przeprowadzonych wśród uczniów jednej ze szkół podstawowych w dzielnicy Achada Grande Frente w Prai (Republika Zielonego Przylądka). W kwietniu 2015 roku szkoła brała udział w projekcie Global Garden Project, Fundacji „W krajobrazie”. W badaniach szczególną uwagę zwrócono na kwestie związane z postrzeganiem krajobrazu w ujęciu edukacji globalnej. Wśród uczniów (8-14 lat) przeprowadzono badania ankietowe oraz wykonano szczegółową analizę prac plastycznych sporządzonych przez dzieci w ramach warsztatów. Przeanalizowano komponenty krajobrazu, rozmieszczenie obiektów na planszach oraz opracowano typologię obiektów dendrologicznych. Analiza i interpretacja prac dzieci jest dobrym źródłem informacji, pomagającym w przygotowania właściwego programu nauczania w zakresie edukacji krajobrazowej.

Słowa kluczowe: postrzeganie krajobrazu, edukacja dziecięca, warsztaty plastyczne

\section{Wprowadzenie}

Wszystkie kraje są ze sobą ściśle powiązane i uzależnione od siebie. Jest to system naczyń połączonych, w których przenikają się ze sobą systemy kulturowe, środowiskowe, ekonomiczne, społeczne, polityczne, technologiczne itp. Jest to coraz bardziej zauważalne i generuje problemy dotykające wszystkich mieszkańców Ziemi. Naprzeciw tej sytuacji wychodzi edukacja globalna, która objaśnia relacje występujące pomiędzy jednostką a procesami globalnymi. W procesie edukacyjnym świat powinien być przedstawiany jako nierozerwalna całość, wspólnota niezliczonych istot, powiązanych ze sobą na wiele sposo- 
bów (Skubała i Kukowka, 2010). Edukacja globalna jest elementem kształcenia obywatelskiego oraz wychowania poświęconym budowaniu świadomości istnienia zjawisk i współzależności o charakterze globalnym. Edukacja globalna koncentruje się na szacunku dla różnych kultur, dla innych ludzi oraz poczuciu odpowiedzialności poszczególnych jednostek za zmiany na świecie (Long i King, 1964). Najpopularniejszymi tematami poruszanymi w ramach edukacji globalnej są prawa człowieka, pokój i bezpieczeństwo, zrównoważony rozwój, problemy rozwoju współczesnego świata, jakość życia i relacje pomiędzy krajami Globalnej Północy i Globalnego Południa. Niezwykle ważną rolę w przygotowywaniu osób do globalnego świata odgrywają nauczyciele, którzy powinni być świadomi spraw globalnych i rozwijać swoje umiejętności radzenia sobie z nimi (Altun, 2017). W kształceniu ustawicznym wielu krajów tematy związane z edukacją globalną poruszane są zazwyczaj w blokach tematycznych takich przedmiotów, jak: geografia, wiedza o społeczeństwie i historia. Są to jednak zazwyczaj tylko drobne wtrącenia do istniejących podstaw programowych. Zainteresowanie edukacją globalną jest natomiast niezwykle popularne wśród organizacji pozarządowych (Gontarska i Kuleta-Hulboj, 2015).

Właściwe kształtowanie krajobrazu jest zagadnieniem, które również powinno stanowić jeden z elementów edukacji globalnej. Ciągłe zmiany w krajobrazach krajów Globalnej Północy doprowadziły w wielu przypadkach do degradacji przestrzeni i nieodwracalnej utraty jej największych atutów. Wraz z coraz większym zainteresowaniem inwestowaniem na Globalnym Południu nanoszona jest z roku na rok nieudolna kalka błędów popełnianych przez wiele lat na swoim „podwórku”. W wielu przypadkach doprowadza to do konfliktów przestrzennych i pomniejszenia walorów krajobrazowych przestrzeni, które powinny być objęte szczególną ochroną. Dochodzi do niezwykle groźnej unifikacji krajobrazów, a w skrajnych przypadkach do utraty tożsamości miejsc budowanych na "nowych” lądach bez poszanowania lokalnych tradycji. Dzieje się tak zarówno w Afryce, Ameryce Południowej, jak i w Azji.

Edukacja krajobrazowa wpisuje się we współczesne trendy i wymagania edukacyjne niezależnie od tego, w jakim ujęciu jest prezentowana (Szczęsna, 2010) i w różnych krajach sprowadza się do innych aspektów edukacyjnych. Estetyzacja przestrzeni kształtuje i rozwija wrażliwość psychiczną oraz aktywność twórczą. Poznawanie i przeżywanie krajobrazu rozwija zainteresowania przyrodnicze i artystyczne, pozwala na samodzielne odkrywanie wartości krajobrazu, co stanowi fundamentalny warunek jego ochrony i poczucia więzi pomiędzy człowiekiem a krajobrazem (Kopczyński, 2009). Edukacja krajobrazowa powinna być prowadzona również w ujęciu globalnym i dużą 
wagę przykładać do nauki krytycznego patrzenia na przestrzeń i konsekwencji związanych z decyzjami planistycznymi. Im wcześniej zaczniemy rozmawiać o estetyzacji przestrzeni i właściwym jej kształtowaniu - tym lepiej. Nie są to jednak tematy łatwe i nie zawsze można je zrealizować w tradycyjnej podstawie programowej w szkole. Przygotowanie nauczycieli w tym zakresie jest również dalekie od ideału. Organizacje pozarządowe, które wśród swoich działań statutowych posiadają zagadnienia związane z ochroną i kształtowaniem krajobrazu, odgrywają w tej kwestii rolę pierwszoplanową.

W niniejszym opracowaniu opisano projekt edukacyjny zrealizowany w jednej z afrykańskich szkół podstawowych. Badania bazowały na wcześniejszych doświadczeniach zbieranych w latach 2012-2015 w Polsce i Kenii (Antolak, 2018). Zorganizowano i przeprowadzono część teoretyczną i praktyczną zajęć dydaktycznych z uczniami. Tematyka zajęć dotyczyła kształtowania krajobrazu w ujęciu globalnym. Celem pośrednim pracy była analiza prac dzieci w zakresie postrzegania przez nie krajobrazu.

\section{Zakres projektu edukacyjnego i metody badań}

Global Garden Project to międzynarodowy projekt o charakterze edukacyjnym realizowany przez Fundację „W krajobrazie”. W ramach projektu powstają przyszkolne ogrody w różnych częściach świata. Ogrody są projektowane i zakładane wspólnie z uczniami. Głównym celami projektu są: realizacja przyszkolnych ogrodów użytkowych o funkcji dydaktycznej, aktywizacja uczniów szkół oraz popularyzacja idei miejskiego ogrodnictwa i foodscapingu. W ramach części teoretycznej zajęć uczniowie biorą udział $\mathrm{w}$ warsztatach plastycznych, projektowych oraz badaniach ankietowych.

W niniejszym artykule opisano wyniki badań przeprowadzonych w kwietniu 2015 roku w szkole podstawowej, położonej w centralnej części dzielnicy Achada Grande Frente, w stolicy Republiki Zielonego Przylądka - Prai. Zakres merytoryczny projektu edukacyjnego objął trzy etapy. Etap przygotowań polegał na nawiązaniu kontaktu z dyrekcją szkoły, opracowaniu materiałów potrzebnych do przeprowadzenia warsztatów, wyborze respondentów i przeprowadzeniu kwerendy bibliotecznej. Etap badań terenowych polegał na przeprowadzeniu obserwacji uczestniczącej, warsztatów rysunkowych i badań ankietowych. Ostatnim etapem pracy był etap analiz i wniosków. Badania przeprowadzono w grupie 25 uczniów (8-14 lat). Zakres wieku uczestników badania dotyczył trzech podstawowych faz twórczości dziecięcej: stadium schematycznego, związanego z opanowywaniem kształtu - ekspresją 
inspirowaną (7-9 lat) stadium początków realizmu (9-12 lat) oraz stadium pseudonaturalistycznym (12-14 lat) (Lowenfeld i Brittain, 1977).

Fot. 1. Warsztaty w Prai, kwiecień 2015 r.

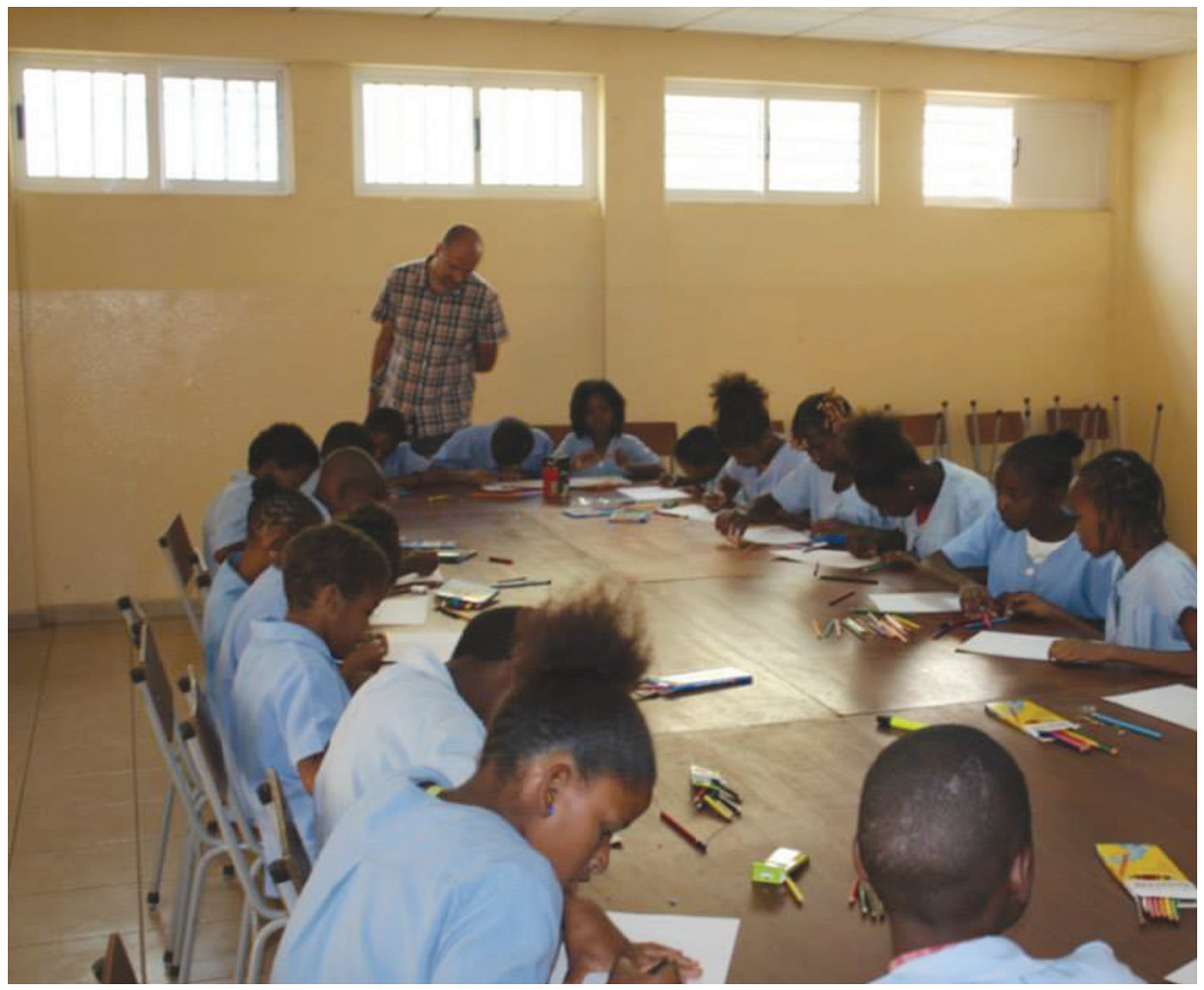

Źródło: Archiwum prywatne Autora.

Warsztaty zrealizowano w trybie zajęć pozalekcyjnych. Wzięli w nich udział wytypowani przez nauczycieli uczniowie z różnych klas. W ramach warsztatów rysunkowych (fot. 1) każde z dzieci miało narysować jedną pracę przedstawiającą krajobraz Republiki Zielonego Przylądka. Dzieci miały do dyspozycji kartki formatu A3 oraz podstawowe narzędzia do rysowania - kredki, ołówki i pastele. Czas pracy określono na 45 minut. Po zakończeniu warsztatów przygotowano wystawę prac uczniów (fot. 2), podczas której każde dziecko omówiło swoją pracę. W ramach prac kameralnych wykonano szczegółową analizę komponentów krajobrazu najczęściej występujących w pracach dzieci. Następnie zdigitalizowano wybrane obiekty i wykonano 
analizę rozmieszczenia tych obiektów na planszach, a także opracowano ich typologię.

Fot. 2. Omawianie prac uczniów, kwiecień 2015 r.

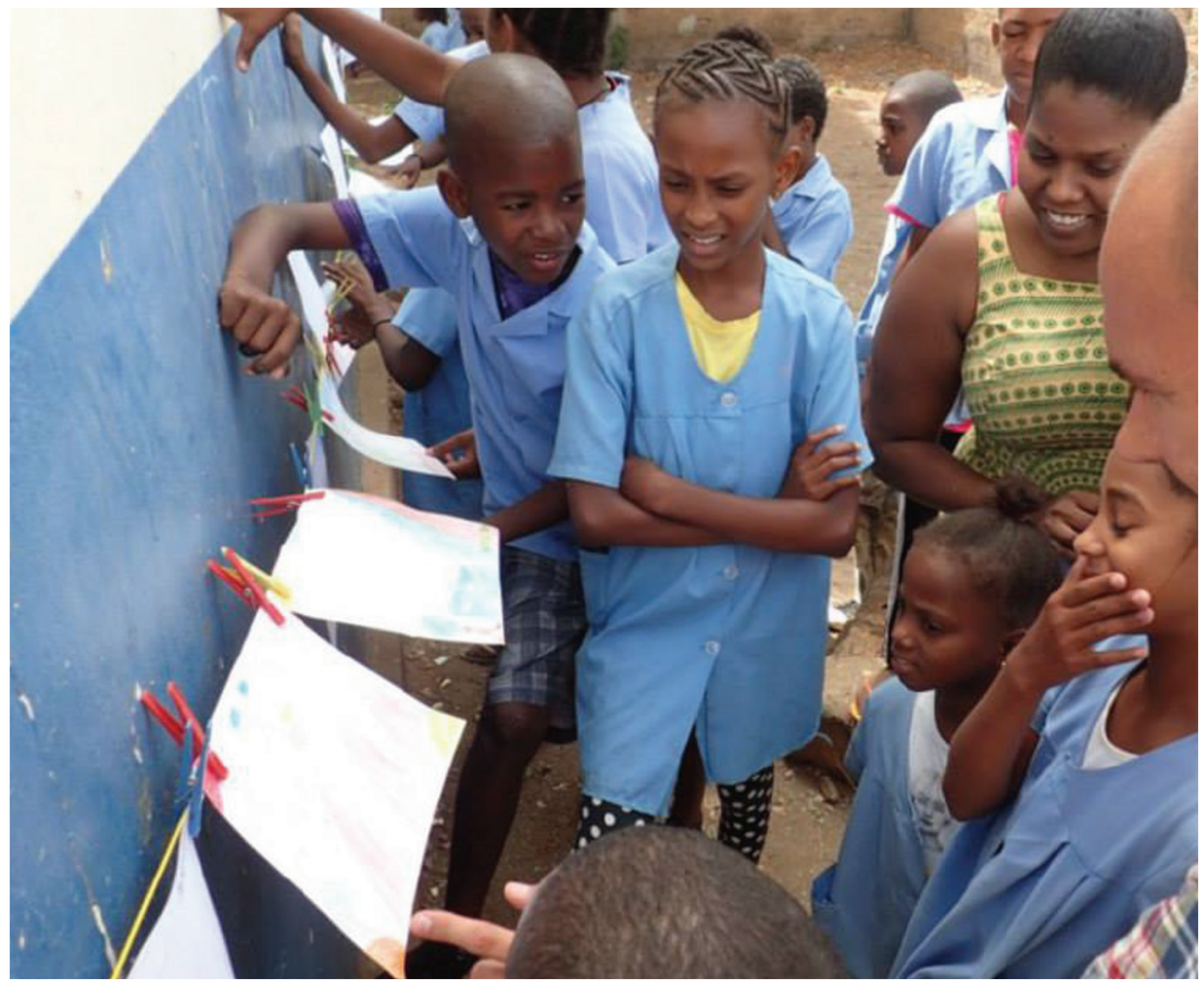

Źródło: Archiwum prywatne autora.

Dodatkowo przeprowadzono badania ankietowe wśród uczestników projektu. Tematyka badań dotyczyła zagadnienia postrzegania krajobrazu i jego wybranych komponentów. Skupiono się w nich na pytaniach dotyczących krajobrazu i drzew - komponentu krajobrazu, występującego w pracach dzieci najczęściej. Respondentom zadano 4 pytania otwarte: 1 . Z jakich elementów składa się krajobraz? 2. Jakie są różnice pomiędzy krajobrazami Polski i Republiki Zielonego Przylądka? 3. Proszę wymienić rodzaje drzew i krzewów rosnących w Republice Zielonego Przylądka. 4. Jakie korzyści dają drzewa? Następnie przeprowadzono z nimi moderowaną dyskusję dotyczącą tematu przewodniego warsztatów. 


\section{Krajobrazy Republiki Zielonego Przylądka}

Wyspy Zielonego Przylądka są demokratyczną republiką. Archipelag wysp jest najbardziej na południe wysuniętą częścią Makaronezji i usytuowany jest we wschodniej części Oceanu Atlantyckiego. Leżące na wschodzie Sal, Boa Vista, Maio, są wyjątkowo płaskie, pozostałe wyspy są natomiast górzyste. Położone są one na przedłużeniu strefy Sahelu, a elementem wpływającym na zasięgi widoczności przez większą część roku jest harmatan. Wyspa Santiago, na której położona jest stolica kraju - Praia - ma powierzchnię 990 km² i charakteryzuje się największym zróżnicowaniem krajobrazowym (fot. 3).

Fot. 3. Typowy krajobraz wyspy Santiago, miejscowość Tarrafal, kwiecień 2015 r.

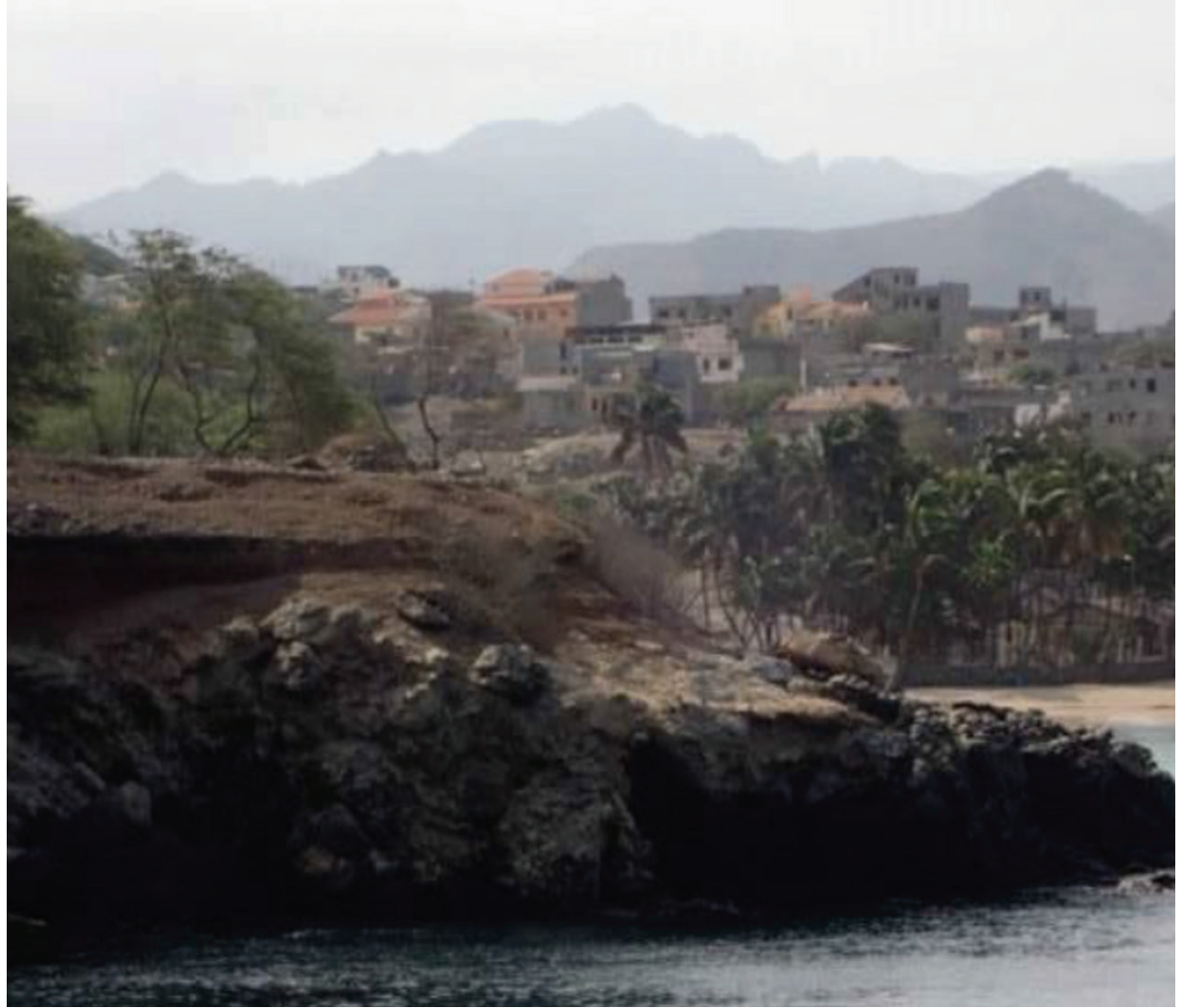

Źródło: M. Antolak. 
We wnętrzu wyspy znajdują się strome góry, z wykorzystywanymi rolniczo "zielonymi” dolinami. Stolica zlokalizowana jest na południowo-wschodnim krańcu wyspy i zamieszkuje ją ok. 150000 mieszkańców. Miasto i jego infrastruktura rozwijają się w szybkim tempie (Irwin i Wilson, 2009). Przy wyborze kraju do badań kierowano się m.in. czynnikiem izolacji przestrzennej. Mieszkańcy tego niewielkiego, wyspiarskiego kraju mają bardzo ograniczony kontakt ze stałym lądem oraz z innymi wyspami (innymi krajobrazami). Lotniska na wielu z wysp zostały pozamykane ze względu na niesprzyjające warunki wietrzne, a wielu mieszkańców cierpi na „chorobę morską”, co przyczynia się jeszcze bardziej do ich izolacji przestrzennej.

Przestrzeń kreowana przez człowieka na wyspach jest harmonijna i spójna. Lokalna architektura nie reprezentuje wysokich walorów, jednak ze względu na dużą jednorodność i wykorzystanie lokalnych materiałów budowlanych jej odbiór jest pozytywny. Dzięki utrudnionemu dostępowi do materiałów konstrukcyjnych i wykończeniowych uzyskała ona jednorodną formę i styl. Przez ograniczony dostęp do wody zieleń urządzona kumulowana jest w bezpośrednim sąsiedztwie zabudowy mieszkaniowej. Mieszkańcy ze względu na utrudnienia w dostępie do roślin ozdobnych najczęściej się nimi wymieniają. Wpływa to pozytywnie na wizerunek przestrzeni sąsiedzkiej. Jest ona wyjątkowo harmonijna i spójna. Budynki są również do siebie podobne, głównie ze względu na ten sam budulec i podobne potrzeby mieszkaniowe. Ważną rolę w społeczeństwie pełnią przestrzenie publiczne. Wieczorami zapełniają się mieszkańcami, którzy spędzają tu większość wolnego czasu. Im bogatsze i większe miasto, tym więcej zieleni urządzonej, która jest na wyspach wyznacznikiem statusu społecznego. Jest to kraj, w którym bardzo łatwo zrozumieć zagadnienie określane mianem krajobrazu dźwiękowego (soundscape). Mieszkańcy wysp szczególną rolę przywiązują do muzyki. Dzieje się tak przede wszystkim za sprawą kolonialnej przeszłości kraju. Dużą rolę w przestrzeniach publicznych odgrywają elementy artystyczne street artu. Elewacje wielu budynków zdobią współczesne murale takich gwiazd światowej sławy, jak: Ozmo, Deih czy Alice Pasquini. Wiele z prac powstało w ramach Festiwalu Sete Sois Sete Luas, który jest organizowany od 1998 roku. Krajobraz stolicy jest silnie zróżnicowany i przekształcony. W mieście występują zarówno ekskluzywne dzielnice z rozbudowaną infrastrukturą techniczną, jak i dzielnice biedy (fot. 4). 
Fot. 4. Krajobraz za murem szkoły, w której przeprowadzano badania, kwiecień 2015 r.

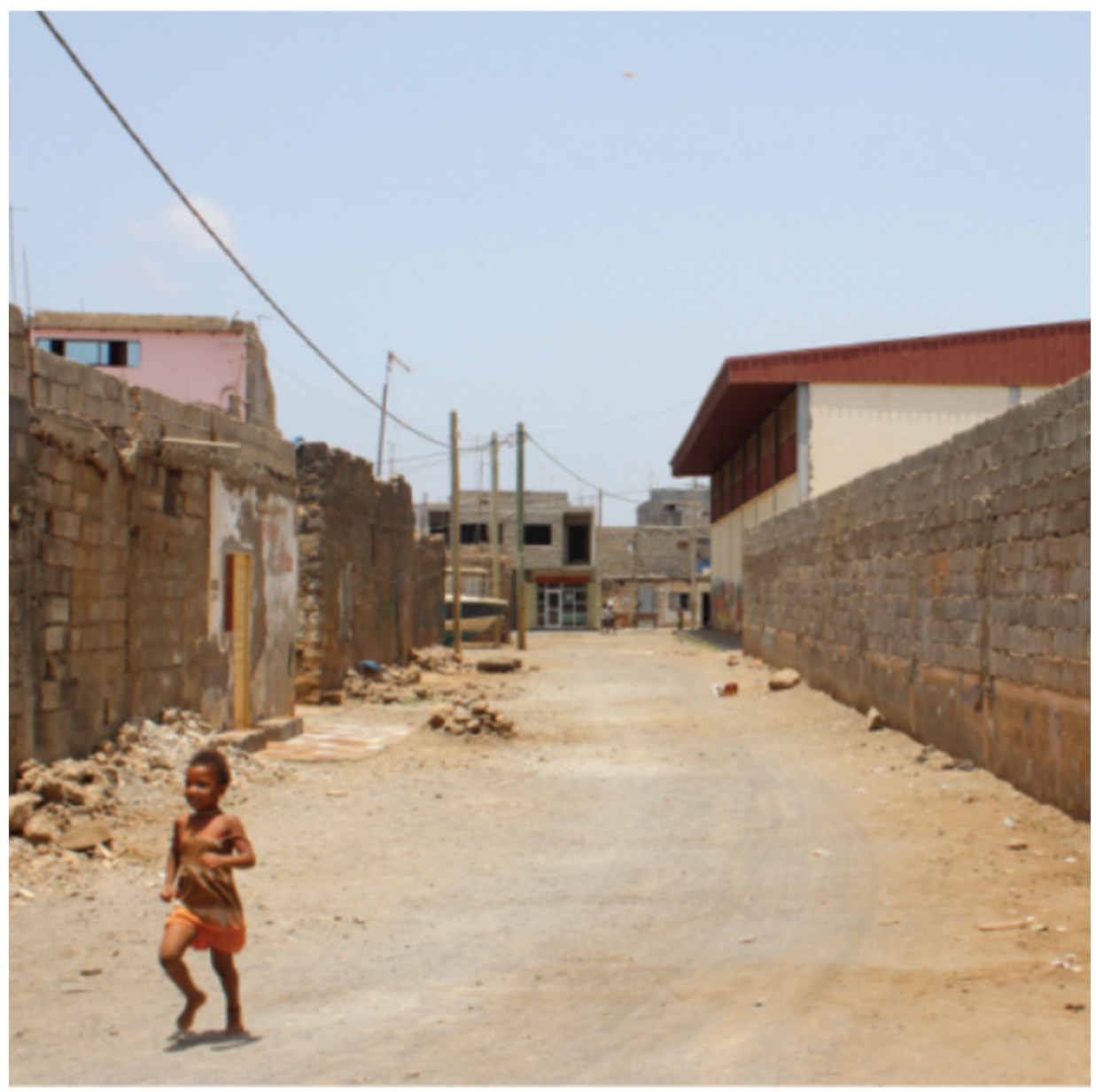

Źródło: M. Antolak.

\section{Global Garden Project Praia - wyniki badań}

W przeanalizowanych pracach pojawiło się 27 różnych komponentów krajobrazu. Dzieci najczęściej rysowały: słońce (88\%), chmury (76\%) i drzewa (72\%). Najczęściej pojawiające się odpowiedzi zaprezentowano w tabeli 1. Respondenci dość często rysowali symbole narodowe (flagi). Zachowanie to może mieć związek zarówno z patriotyzmem lokalnym, jak i trudnością w przypisaniu konkretnych składowych krajobrazu do swojej ojczyzny. Po- 
pularnymi wskazaniami były góry, wulkany i wody powierzchniowe - elementy będące wizytówką Zielonego Przylądka. W pracach młodszych dzieci krajobraz wysp prezentowany był w postaci jednego stożka wulkanicznego w czasie erupcji. Kolorystyka prac utrzymana była często w brązowych tonacjach, niewiele było w nich odcieni zieleni. Elementami wskazywanymi przez pojedyncze osoby były: zwierzę, ogród/pole uprawne, krzew, parking, chodnik i wodospad.

Dzieci wykazywały się stosunkowo dużą dokładnością, szczególnie wypełniając narysowane wcześniej kontury kolorem. Preferowanym narzędziem wykorzystywanym do tworzenia prac plastycznych były kredki ołówkowe. Uczniowie chętnie korzystali z gumek. Na każdej z prac oprócz imienia, nazwiska i wieku autora (o co dzieci zostały poproszone) pojawiła się również data. Charakterystycznym elementem prac były powtarzające się schematy rysunkowe. Dzieci w podobny sposób prezentowały takie elementy jak ptaki, słońce, chmury czy drzewa. Komponenty krajobrazu były prezentowane w postaci scen rodzajowych, tworząc w wielu przypadkach logiczną całość. Na planszach często pojawiały się motywy związane z turystycznym wykorzystaniem przestrzeni. Poniżej zaprezentowano dwie przykładowe prace, które powstały w ramach warsztatów.

Tabela 1. Zestawienie najpopularniejszych wskazań uczestników warsztatów plastycznych

\begin{tabular}{|l|c|c|}
\hline \multicolumn{1}{|c|}{$\begin{array}{c}\text { Komponent } \\
\text { krajobrazu }\end{array}$} & $\begin{array}{c}\text { Liczba wskazań } \\
\text { wswskazańwskazań }\end{array}$ & $\begin{array}{c}\text { Udział w \% } \\
\text { proprocentowy }\end{array}$ \\
\hline Słońce & 22 & 88,0 \\
\hline Chmura & 19 & 76,0 \\
\hline Drzewo & 18 & 72,0 \\
\hline Góra & 14 & 56,0 \\
\hline Wulkan & 9 & 36,0 \\
\hline Ocean & 8 & 32,0 \\
\hline Bydynek mieszkalny & 6 & 24,0 \\
\hline Niebo & 6 & 24,0 \\
\hline Człowiek (turysta) & 5 & 20,0 \\
\hline Flaga kraju & 5 & 20,0 \\
\hline Ptaki & 4 & 16,0 \\
\hline Droga & 3 & 12,0 \\
\hline Warzywa & 3 & 12,0 \\
\hline $\begin{array}{l}\text { Samochód, statek, deszcz, ryby, parasol i leżak pla- } \\
\text { żowy, trawnik, warzywa, ogrodnicy/rolnicy... }\end{array}$ & 2 & 8,0 \\
\hline
\end{tabular}

Źródło: Opracowanie własne. 
Ryc. 1. Praca 14-letniej uczennicy

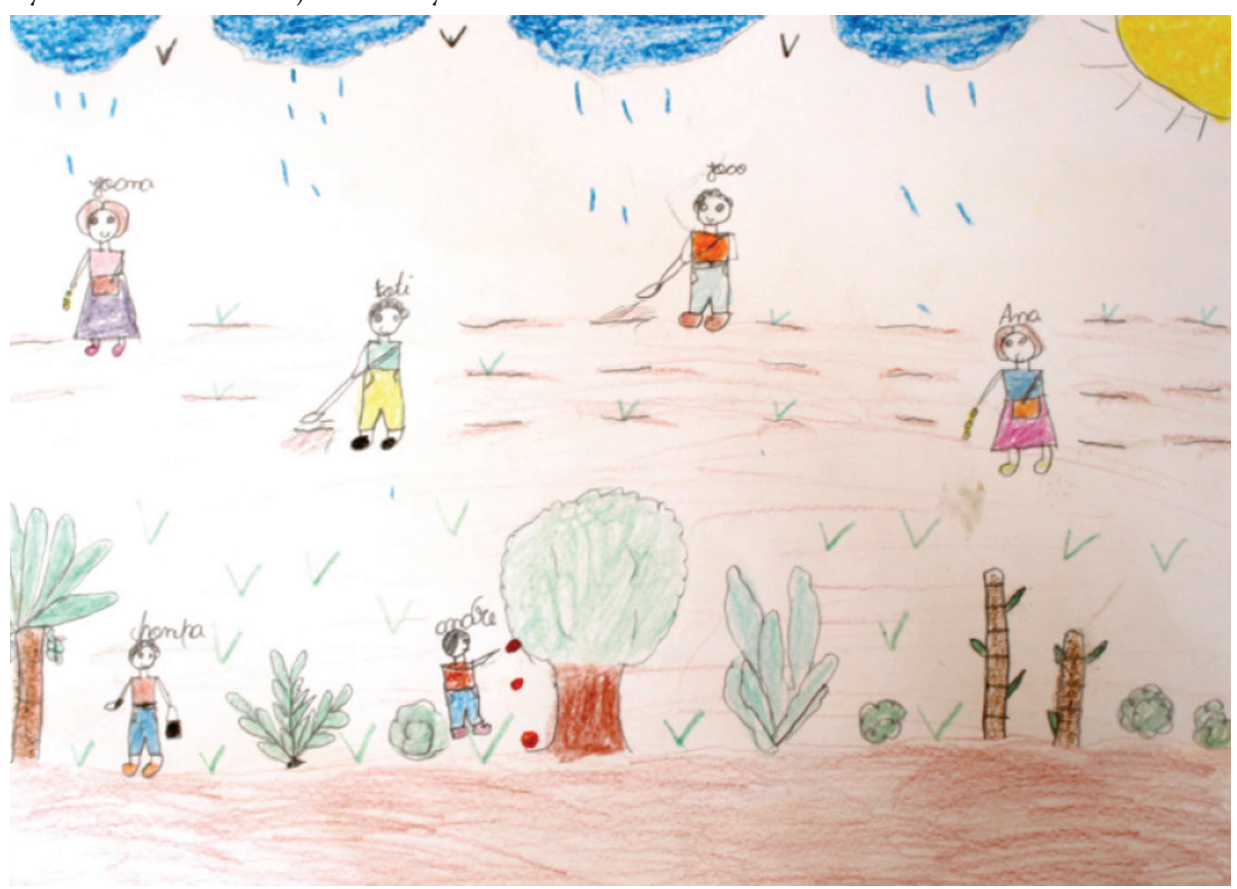

Źródło: Materiał stworzony podczas warsztatów rysunkowych.

Rysunek 14-letniej uczennicy - najstarszej uczestniczki warsztatów (ryc. 1) przedstawia krajobraz rolniczy. W dolnej części pracy umieszczono sad z drzewami i krzewami owocowymi oraz warzywami rosnącymi w sąsiedztwie. Powyżej uczennica narysowała pole uprawne z pracującymi na nim rolnikami/ogrodnikami. Istotnym elementem rysunku jest padający deszcz, który na wyspach pojawia się niezwykle rzadko i uzależnione jest od niego w dużej mierze lokalne rolnictwo. Kraj boryka się z problemami w zaresie pozyskania słodkiej wody pitnej i użytkowej. Szkoła, w której prowadzono warsztaty, nie miała dostępu do bieżącej wody i była ona dowożona tylko w beczkach. W pracy zauważalny jest wyraźny rytm. Na uwagę zasługują ponadto podpisy poszczególnych postaci tej scenki rodzajowej. Uczestniczka warsztatów jest reprezentantką stadium pseudonaturalistycznego. Rysunki tego okresu odzwierciedlają naturalistyczne postrzeganie świata. Prace są mniej schematyczne, a dziecko staje się bardziej krytyczne wobec własnej twórczości. Rysunki postaci ludzkich zawierają więcej szczegółów. 
Ryc. 2. Praca 11-letniej uczennicy

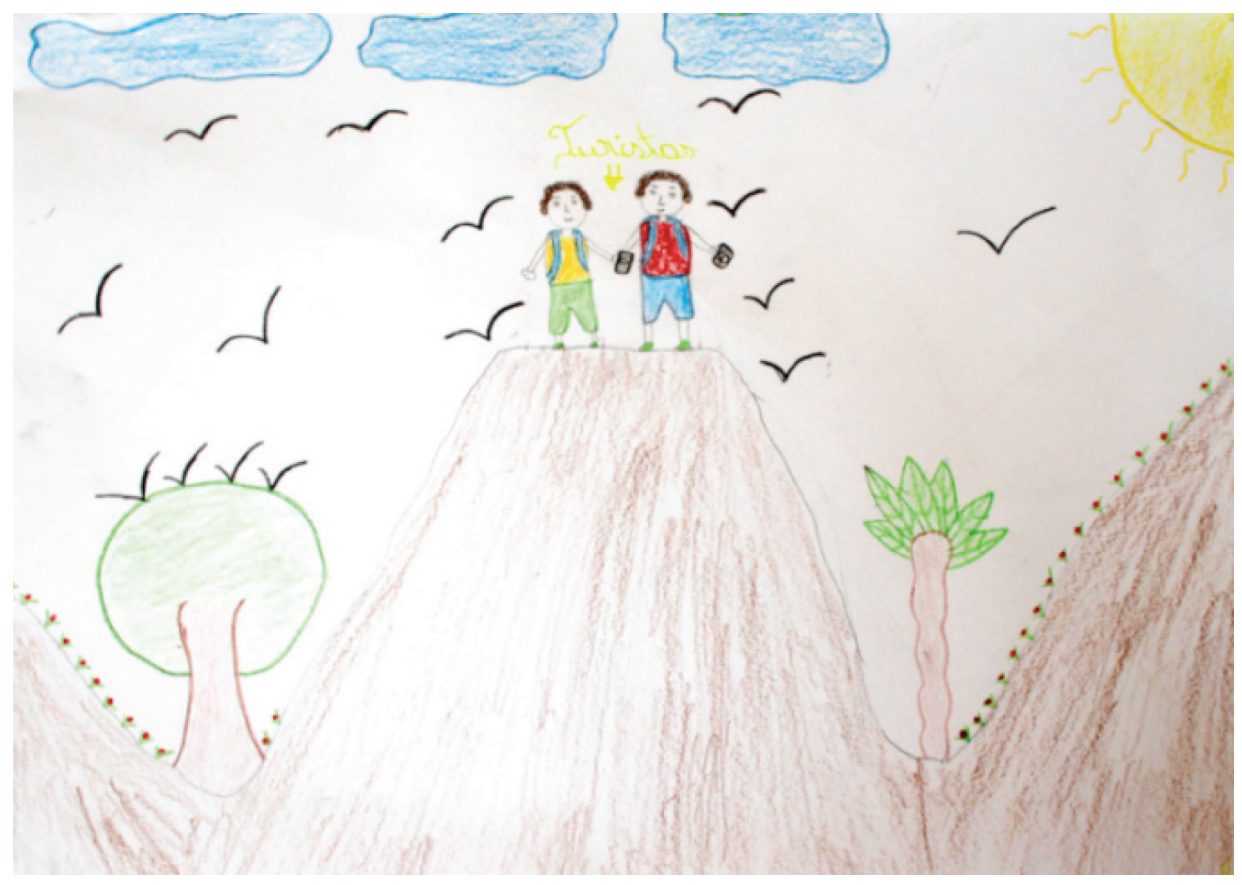

Źródło: Materiał stworzony podczas warsztatów rysunkowych.

Praca 11-letniej dziewczynki (ryc. 2) przedstawia turystów zwiedzających górzysty krajobraz wysp. W pracy zaprezentowano trzy wzniesienia oraz znajdujące się pomiędzy nimi doliny porośnięte roślinnością. Nad wzniesieniami oraz na drzewach narysowane zostały $w$ formie schematycznej ptaki. Turyści zostali zaprezentowani z aparatami fotograficznymi w rękach. Praca została stworzona przez uczennicę w wieku stadium początków realizmu. Jest to tzw. okres grup rówieśniczych, w którym zanika powtarzanie tych samych form. Na ich miejsce pojawiają się nowe kształty oraz techniki wykonywania prac plastycznych. Dzieci wyodrębniają w tym okresie więcej szczegółów. Ich rysunki raczej symbolizują, niż prezentują świat przedmiotów.

Krajobraz przez uczestników warsztatów jest odbierany jako przestrzeń dająca wiele korzyści (m.in. wykorzystanie rolnicze i turystyczne). Ze względu na fakt, iż już od kilku lat uczęszczają do szkoły, nauczyły się prezentować składowe krajobrazu przy użyciu charakterystycznych schematów. Najcenniejsze są prace dzieci młodszych, które przestawiają ich własne wyobrażenie krajobrazu, a nie to, co zwykle podpowiadali im nauczyciele i rodzice. 
Zaprezentowane w pracach dzieci komponenty krajobrazu można podzielić na dwie grupy: obiekty występujące w najbliższym otoczeniu oraz te, które są utożsamiane z krajem. Jako składowe krajobrazu uczestnicy warsztatów wymieniali zazwyczaj elementy harmonijne.

Krajobraz prezentowany w pracach dzieci starszych był najczęściej odwzorowaniem rzeczywistości, u młodszych natomiast wyobrażeń o przestrzeni doskonałej. Większość z narysowanych przez dzieci obiektów tworzyło spójną scenerię (luźno rozmieszczone na kartkach elementy). W pracach młodszych dzieci przeważa krajobraz górski, w którym dominują wulkany w czasie erupcji. Większość prac charakteryzuje kompozycja otwarta. Jest to zabieg mający na celu pobudzenie wyobraźni odbiorcy, poprzez chęci myślowego dokończenia poszczególnych elementów ilustracji, niemieszczących się w obrębie granic kartki papieru. Cechami prac plastycznych dzieci młodszych są czytelność, jasność przekazu oraz tendencja do wyraźnego podkreślania porządku istniejącego świata poprzez powielanie utartego i dobrze znanego schematu. Świadczyć może to o potrzebie uporządkowania świata i nadania mu miana bezpiecznego, przyjaznego i tolerancyjnego (Cierkosz, 2013).

Na 25 rysunkach pojawiło się 67 drzew, co daje średnią 2,7 drzewa na rysunek. Elementy te zostały narysowane w 18 pracach, co świadczy o dużej roli, jaką odgrywają drzewa w krajobrazie. Jest to szczególnie interesujące, biorąc pod uwagę to, iż na wyspach występują one sporadycznie. Niewiele jest tu kompleksów leśnych, a drzewa sadzone są przeważnie w miastach oraz w ogrodach - pełniąc głównie funkcje ozdobne i użytkowe. Obiekty zlokalizowane są przede wszystkim w centralnej części kartki. Ich wielkość jest bardzo zróżnicowana. Drzewa na rysunkach uczniów rosną często w dolinach rzecznych lub w sadach. Przypisano je do 5 typów: owocowe (pojedyncze), owocowe (sad), kulista korona, palma, bananowiec (ryc. 3). Obiekty dendrologiczne prezentowane są w postaci ogólnych schematów, prezentujących ich zróżnicowanie morfologiczne (pień i korona). Dość często w pracach pojawiają się również owoce, podkreślające rangę utylitarności. Wydzielono dwa podstawowe typy drzew (owocowe i ozdobne) oraz liczne podtypy, różniące się od siebie przede wszystkim kształtem i wielkością korony. Drzewa prezentowane są w formie okazów, z których można pozyskiwać owoce, liście, kwiaty, korzenie. W pracach można zauważyć jednak też tendencję do zauważania ich cech wpływających na estetyzację przestrzeni. 
Ryc. 3. Wizualizacja graficzna wszystkich drzew narysowanych przez dzieci w ramach warsztatów (obiekty zdigitalizowane i nałożone na jedną kartkę) oraz typologia tych obiektów

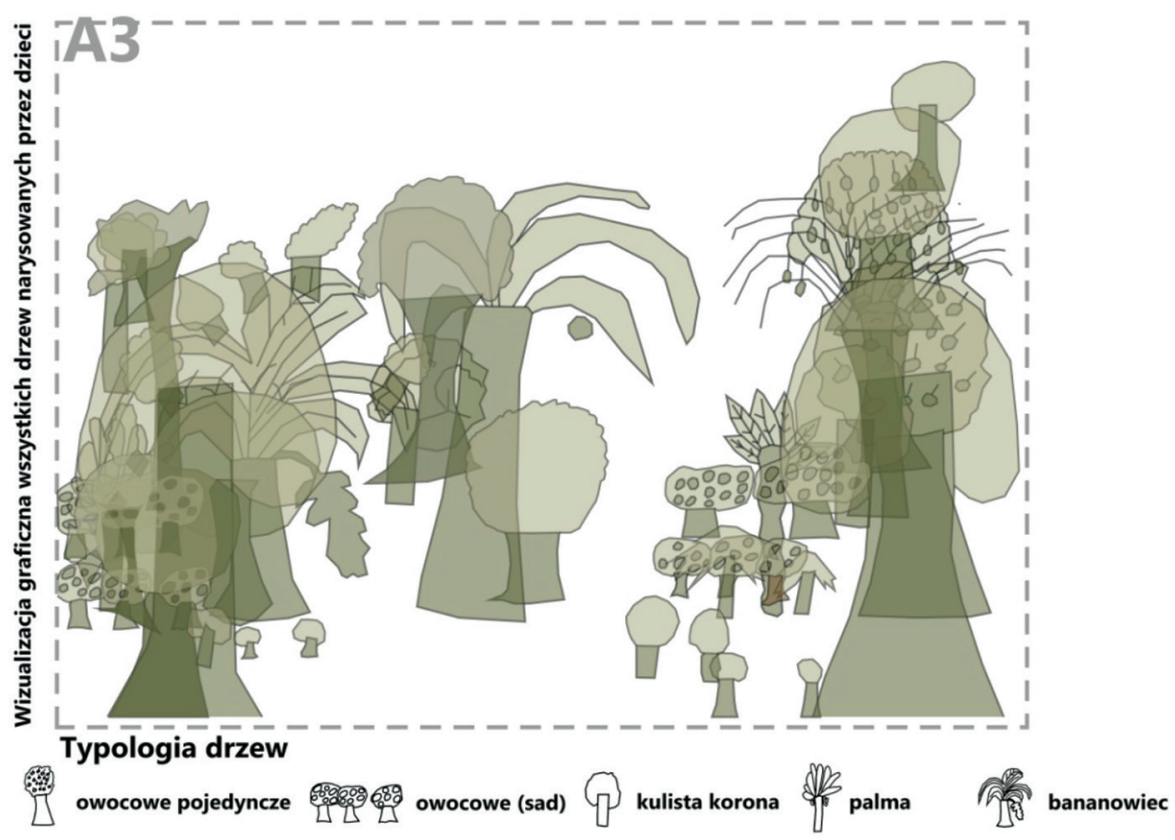

Źródło: Opracowanie własne.

Ocena i interpretacja rysunku jest uznaną metodą diagnostyczną stosowaną przez psychologów, pedagogów, terapeutów, a także przez lekarzy. Rysunki dzieci analizowane są na wiele różnych sposobów i pomagają w komunikowaniu się z nimi (Nazaruk i Konovaluk, 2012). Najczęściej dostarczają wiedzy na temat osobowości i życia autorów prac. Ich odpowiednia interpretacja potrafi wiele powiedzieć o dziecku (Duksa, 2011). Dzieci, tworząc swobodne prace plastyczne, dążą do pierwotnego kanonu piękna (proporcja, symetria, ład i harmonia), którego znajomość stanowi podstawę wszelkiego rodzaju przedsięwzięć artystycznych. Młodzi twórcy posiadają wyobraźnię pozwalającą na idealizowanie otaczającej ich rzeczywistości, a z ich prac możemy wyczytać wyraźny przekaz, który nie będzie już tak czytelny, gdy dorosną (Cierkosz, 2013).

Po warsztatach plastycznych - respondenci poproszeni zostali o udzielenie odpowiedzi na 4 pytania otwarte. Pytania dotyczyły krajobrazu oraz drzew. Dzieci bez większych problemów wymieniały podstawowe komponenty krajobrazu oraz różnice i podobieństwa zaobserwowane pomiędzy polskimi a kabo- 
werdyjskimi krajobrazami. Wśród komponentów krajobrazu uczestnicy badań ankietowych wymieniali najczęściej, takie jak: góra, ocean, roślina, ptak, droga, budynek, chmura i wulkan. Wśród wskazań zabrakło niektórych z elementów, które pojawiały się często na rysunkach uczniów (słońce, niebo, człowiek, flaga). Dzieciom zaprezentowano kilkadziesiąt zdjęć pochodzących z różnych regionów Polski i poproszono ich o wskazanie różnic pomiędzy tym, co widzą na zdjęciach, a tym co obserwują na co dzień w swoim kraju. Zaobserwowane różnice dotyczyły najczęściej zwierząt, lasów, kwiatów, rzek, klimatu, plaż, ilości opadów atmosferycznych. Mimo tego, iż pytanie dotyczyło różnic w postrzeganiu krajobrazów, wśród odpowiedzi znalazły się takie wskazania, jak: język i muzyka, które odgrywają w tym kraju niezwykle ważną rolę. Respondenci zauważyli również brak wulkanów. Ciekawą obserwacją było wskazanie różnicy w kolorach porównywanych krajów (harmatan) i muzyki, traktowanej jako elementu składowego krajobrazu (soundscape). Uczestnicy warsztatów mieli pewne problemy z wymienieniem nazw popularnie występujących w okolicy ich zamieszkania drzew i krzewów. Uczniowie wymienili zaledwie 7 nazw roślin (bawełna, tamaryndowiec, agawa sizalowa, melonowiec, mango, winogrono i gujawa). Jest to zastanawiające tym bardziej, że przy szkole znajduje się użytkowy ogród z częścią sadowniczą i licznymi roślinami ozdobnymi. Wśród wskazań brakuje roślin ozdobnych, nieutożsamianych z funkcjami użytkowymi. Zdaniem respondentów podstawowymi korzyściami, jakie otrzymujemy od drzew, jest pokarm. Uczniowie wymieniali takie benefity, jak: owoce, drewno, płatki kwiatów, herbata, jadalne korzenie, kawa, kakao, perfumy, rzeczy, których używamy na co dzień.

\section{Podsumowanie i wnioski}

Zmiany w krajobrazach, które mają obecnie miejsce na świecie, są bardzo niepokojące i wymagają podjęcia konkretnych interwencji. Mają one charakter globalny, dlatego też edukacja globalna powinna być brana pod uwagę jako jedno z narzędzi o charakterze zapobiegawczym. Wiedza i wrażliwość na piękno krajobrazów społeczności zamieszkujących wszystkie kontynenty jest niewielka, posiada jednak wspólne mianowniki. Przy ocenach swojego najbliższego otoczenia jesteśmy zdecydowanie bardziej surowi niż w przypadku terenów położonych poza zasięgiem naszego wzroku. Naukę właściwego kształtowania krajobrazu należy rozpocząć jak najwcześniej. W wieku szkolnym dużo łatwiej ukształtować i utrwalić właściwe wzorce zachowań i postaw. Niezwykle ważną rolę w kształtowaniu właściwych postaw w tej 
tematyce odgrywają organizacje pozarządowe. Realizując różnego rodzaju formy zajęć pozalekcyjnych, skierowanych do różnych grup społecznych, uzupełniają lukę występującą w edukacji systemowej.

Edukacja krajobrazowa odgrywa ważną rolę szczególnie w małych, odizolowanych społecznościach. Daje okazję pokazania zróżnicowania krajobrazowego innych kontynentów oraz gwałtownych zmian, jakie występują w innych krajobrazach. Niewielkim, odizolowanym grupom łatwiej uwierzyć w siłę sprawczą jednostki. W procesie dydaktycznym warto podnosić te kwestie, wychodząc z założenia, że zmiany należy zaczynać od siebie. Warto podkreślać, że wszystko zaczyna się od małych zmian, za które jesteśmy sami odpowiedzialni (kolor elewacji budynku, uporządkowana strefa frontowa, zieleń). Ważne jest zrozumienie tego, że zmiany w krajobrazie mają charakter długookresowy i nie wiążą się wyłącznie z pomniejszeniem walorów estetycznych. Prezentacja dobrych i złych przykładów działań z różnych zakątków świata pomaga w lepszym zrozumieniu tego, że zmiany krajobrazu mogą wiązać się też np. ze zmianami klimatycznymi.

W pracy opisano wyniki badań przeprowadzonych w ramach międzynarodowego projektu edukacyjnego pn. Global Garden Project Praia (Republika Zielonego Przylądka). Warsztaty plastyczne, stanowiące jeden z elementów projektu, pozwalają dzieciom zrozumieć abstrakcyjne pojęcie, jakim jest dla nich „krajobraz”. Proste zadanie, jakim jest narysowanie krajobrazu swojego kraju, może początkowo przysparzać wielu problemów. Żeby wyciągnąć właściwe wnioski z prac uczestników warsztatów, ważne jest zapewnienie kilku podstawowych zasad. Każdy z uczestników powinien mieć zapewnione porównywalne warunki pracy i mieć ograniczony kontakt z innymi osobami rysującymi. Nacisk ze strony otoczenia na zachowanie dziecka może spowodować zahamowanie jego ekspresji twórczej. Na zajęciach powinna panować atmosfera swobody i tolerancji, która stwarza klimat zachęty do eksperymentowania. Grupy warsztatowe nie powinny być zbyt licznie (maksymalnie 25-osobowe), zróżnicowane wiekowo, a uczniowie powinni pochodzić z różnych klas. Prowadzący warsztaty powinien pracować z nauczycielem, którego znają uczniowie. Pojawienie się w szkole osoby z zewnątrz pomaga m. in. w dłuższym skupieniu uwagi. Bardzo ważne, aby przekonać nie tylko dzieci, ale też nauczycieli z danej jednostki, o słuszności przekazywanych w ramach warsztatów treści. A gdzie uczyć? Oczywiście najlepiej podczas wspólnej pracy. Najlepiej w przyszkolnym ogrodzie. Taka wiedza zostaje w głowach dużo dłużej niż ta, którą przekazujemy uczniom siedzącym w szkolnych ławkach. Pozwala to również na zmniejszenie dystansu pomiędzy prowadzącym 
warsztaty, a uczniami. Niezwykle ważne są: pasja, zaangażowanie, naturalność i prawdziwość osoby prowadzącej zajęcia.

Analiza i interpretacja prac dzieci jest dobrym źródłem informacji, pomagającym w przygotowania właściwego programu nauczania w zakresie edukacji krajobrazowej. Zajęcia plastyczne warto zaplanować w początkowej części warsztatów i dopiero po analizie prac stworzonych przez uczniów przejść do merytorycznej części zajęć. Należy je wzbogacić o problemy zaobserwowane na pracach dzieci. Przed przystąpieniem do analizy prac dobrze jest szczegółowo zapoznać się z aktualną, miejscową sytuacją gospodarczą, polityczną, kulturową, która często znajduje odzwierciedlenie w pracach dzieci. Po stworzeniu prac należy umożliwić każdemu z uczestników warsztatów prezentację swojej pracy. Warto uczyć o tym, że krajobraz nie uznaje podziałów administracyjnych, że jest to nasze wspólne dobro. Czyli mówić o rzeczach banalnych, ale takich, o których niestety bardzo często zapominają deweloperzy, inwestorzy i włodarze przestrzeni.

\section{Bibliografia}

Altun, M. 2017. What Global Education Should Focus on. International Journal of Social Sciences E Educational Studies. 4 (1), pp. 82-86.

Antolak, M. 2018. Art Therapy in The Mathare Slum (Nairobi, Kenya). In: Conference Proceedings, 5th International Multidisciplinary Scientific Conference on Social Sciences E Arts, SGEM 2018. Albena, Bulgaria. 5 (3-4), pp. 55-62.

Cierkosz, I. 2013. Analiza prac plastycznych dzieci z perspektywy klasycznego postrzegania piękna. Przegląd Pedagogiczny. 2, ss. 85-97.

Duksa, P. 2011. Rysunek dziecka w diagnozie psychopedagogicznej. Studia Elblaskie. 12, ss. 425-435.

Gontarska, M. i Kaleta-Hulboj, M. 2015. Wprowadzenie: Edukacja globalna. Polskie konteksty i inspiracje. W: Kaleta-Hulboj, M. i Gontarska, M. red. Edukacja globalna. Polskie konteksty i inspiracje. Wrocław: Wydawnictwo Naukowe Dolnośląskiej Szkoły Wyższej, ss. 4-15.

Irwin, A. i Wilson, C. 2009. Wyspy Zielonego Przyladka. Warszawa: PWN. Kopczyński, K. 2009. Edukacyjne walory krajobrazu kulturowego. Problemy Ekologii Krajobrazu. 25, ss. 53-62.

Lipska-Badoti, G., Rostek, B., Szczygieł, P. i Witkowski, J. 2011. Edukacja globalna $w$ szkole. Warszawa: Wyd. Centrum Edukacji Obywatelskiej, PAH. Long, H.M. and King, R.N. 1964. Improving the Teaching of World Affairs: 
The Glens Falls Story. Washington: National Council for the Social Studies.

Lowenfeld, V. and Brittain, W.L. 1977. Twórczość a rozwój umystowy dziecka. Warszawa: PWN.

Łosiewicz, A. 2002. Rysowanie odzwierciedla myślenie dziecka. Edukacja i Dialog. 10, ss. 37.

Nazaruk, S. i Konovaluk, E. 2012. Rysunek w wychowaniu przedszkolnym

- rola w diagnostyce i terapii pedagogicznej. Rozprawy Społeczne. 1 (6), ss. 5-20.

Skubała, P. i Kukowka, I. 2010. Zrozumieć przyrodę na nowo. 10 zasad jak uczyć o przyrodzie, by budować motywację do działań ekologicznych. Zeszyty Ekologiczne. 1. Bystra: Wyd. Pracownia na rzecz Wszystkich Istot. Szczęsna, J. 2010. Koncepcja edukacji krajobrazowej na poziomie szkolnym w odniesieniu do kierunków nauki o krajobrazie. Annales Universitatis Mariae Curie - Skłodowska Lublin - Polonia. 65 (1B), ss. 137-157.

\title{
Global education of children in landscape shaping - Global Garden Project Praia (The Republic of Cabo Verde)
}

\begin{abstract}
Global education puts particular emphasis on showing the relationship between an individual and the global processes (Lipska-Badoti i in., 2011) which include changes in the landscape. It helps to shape responsible attitudes from an early age, independently from the place of residence. This paper presents the results of a survey conducted among students of one primary school in the Achada Grande Frente district of Praia (Cape Verde). In April 2015, the school took part in "In the Landscape" Foundation project entitled Global Garden Project. During the research, particular attention was paid to the issues related to the perception of landscape in terms of global education. A questionnaire survey and artistic workshops were carried out among the school's students (children aged 8-14). After that a detailed analysis of these artworks was made. The components of the landscape, objects spaced on the pieces of paper were analyzed, and a typology of dendrological objects were developed. The analysis and interpretation of children's works is a good source of information, helping to prepare an appropriate curriculum in the field of landscape education.
\end{abstract}

Keywords: landscape perception, childhood education, artistic workshops 